\section{Teoría en fuga}

\author{
2 Graciela Montaldo / Columbia University \\ gm2168@columbia.edu
}

\section{Resumen}

El artículo se interroga por los sentidos y la posibilidad de la teoría y la crítica en la cultura contemporánea. En la primera parte se plantea cómo la teoría se instala como discurso político y politizado durante algunos momentos del siglo $\mathrm{xx}$; se analiza su inserción en el campo profesional y su relación con las instituciones. En un segundo momento, se interroga por la relación de la teoría con el mercado y se plantea su ingreso a un sistema de profesionalización del pensamiento crítico hacia fines del siglo xx. Posteriormente se analizan algunos casos en los que la teoría se pone en escena como acto de lectura y acto político en películas de Kluge y Mitre. Finalmente, se analiza el ingreso de la teoría en la cultura argentina, como una manera radical de crear una nueva identidad intelectual y las discusiones que generó el nuevo modelo. En el artículo se discuten ideas de Paul de Man, Edward W. Said, Jacques Rancière, Carlos Correas, David Viñas, entre otros. A partir de las ideas de Rancière sobre la igualdad y la emancipación, me interesa ver cómo las teorías no sólo viajan (en la terminología de Edward W. Said) sino que además son colonizadas por otros contextos intelectuales.

Palabras clave: Teoría $\cdot$ cultura $\cdot$ industria cultural • Argentina $\cdot$ años 60

\section{Abstract}

This article interrogates the meaning and possibilities of theory and criticism in contemporary culture. The first part is focused on how theory settles as political and politized discourse during precise moments of the twentieth century; I study its location in the profession and the relationship with institutions. The second part of the article analyzes the links between theory and the market and how theory became part of the professional system during the end of the century. Later, I study some cases in which theory performes as Reading act and political act in Kuge's and Mitre's films. Finally, I discuss the entry of theory in Argentine culture as a way to create new intellectual identities. In the article, I also discuss the ideas of Paul de Man, Edward W. Said, Jacques Rancière, Carlos Correas, David Viñas, between others. Regarding Rancière's ideas on equality and emancipation, I will focus on the Latin American context to study how theories are not just «traveling theories» (as Edward W. Said called them) but discourses that are colonized by new intellectual contexts.
Key words: Theory $\cdot$ culture $\cdot$ culture industry $\cdot$

Argentina $\cdot$ Sixties 